\title{
PHENOTYPIC CHARACTERISTICS AND BIOMETRICAL STUDY ON DIFFERENT BREEDS OF PIGEON IN NORTHERN BANGLADESH
}

\author{
M. N. H. Parvez ${ }^{1,2^{*}}$, M. T. D. Akter² and M. J. U. Sarder ${ }^{2}$ \\ ${ }^{1}$ Department of Anatomy and Histology, Hajee Mohammad Danesh Science and Technology University, \\ Dinajpur-5200, Bangladesh; ${ }^{2}$ Department of Veterinary and Animal Sciences, University of Rajshahi, Rajshahi- \\ 6205, Bangladesh
}

\begin{abstract}
The experiment was conducted to characterize different breeds of pigeon phenotypically and to study their body biometry, which are available in the northern Bangladesh. During this study 30 farms were selected which have $>20$ pair of pigeons in the three study area namely Rajshahi, Natore and Pabna districts of Bangladesh. There about 15 breeds have been selected for the observation of phenotypic characteristics such as color of bill, eye, eyelid, skin, shank, toe, egg, head feather, neck feather, body feather, down feather, wing feather, tail feather and shape of bill, body and egg. The biometrical data were collected from the measurement of length of bill, head, body, shank, middle toe, wingspan and mature body weight. In this study the highest mean bill length was found $2.83 \pm 0.05 \mathrm{~cm}$ in Strasser and lowest mean head length $5.00 \pm 0.00 \mathrm{~cm}$ in Kormona, Nun and Jacobin. The highest mean body length was found $41.60 \pm 0.38 \mathrm{~cm}$ in Strasser and lowest mean body length $30.00 \pm 0.43 \mathrm{~cm}$ in Owl. The highest mean wingspan was found $81.00 \pm 0.51 \mathrm{~cm}$ in Jacobin and lowest mean wingspan $60.45 \pm 0.76 \mathrm{~cm}$ in kormona. The heighest mean shank length was found $3.40 \pm 0.13 \mathrm{~cm}$ in Homer and lowest mean shank length $2.50 \pm 0.00 \mathrm{~cm}$ in Giribug, Kormona, Nun, Satinette and Suachandan. The heighest mean middle toe length was found $4.40 \pm 0.05 \mathrm{~cm}$ in pouter and lowest mean middle toe length $3.00 \pm 0.00 \mathrm{~cm}$ in kormona. The heighest mean mature body weight was found $748.20 \pm 8.96 \mathrm{gm}$ in Strasser and lowest mean mature body weight $265.10 \pm 7.03 \mathrm{gm}$ in Giribug. Phenotypic correlation among bill length, head length, body length, wing span, shank length, middle toe length and mature body weight of these breeds of pigeon ranged from 0.233 to 0.789 . The experiment's result may contribute to breed up gradation, helps to formulate the conservation and improvement strategies for the breed as genetic resource.
\end{abstract}

Key words: Pigeon, breed, phenotypic characters, biometry

\section{INTRODUCTION}

Pigeon, common name for members of the large family Columbidae, land birds, cosmopolitan in temperate and tropical regions, characterized by stout bodies, short necks, small heads, and thick, heavy plumage (Gifford, 1941). Pigeons are incredibly complex and intelligent animals. Pigeons (Order Columbiformes) are ubiquitous birds and can be found in virtually every town and city around the globe (Marques et al. 2007). They are highly dependent on humans to provide them with food and sites for roosting, loafing, and nesting. They live side by side with human as a source of food, hobby and experimental purposes (Sari et al. 2008). Although pigeons are one of the most intelligent of all the bird species man has found limited uses for the birds other than for the purposes of sport, food and as a message carrier. Bangladesh has a long historical record of raising poultry under backyard system (Bhowmik, 2014). The weather and vast areas of crop field along with housing premises of Bangladesh are suitable for pigeon farming (Asaduzzaman et al., 2009). Mbap (1985) suggested that before attempting any genetic improvement, animals must first be characterized. The future utilization of genetic resource depends on breed characterization (FAO, 2010). Present status of a livestock breed in terms of breed characteristics is essential to formulate the conservation and improvement strategies for the breed. Pigeons are mainly monogamous birds (Essam, 1997). Courtship display of pigeon is usually performed by the male, and shown by the fluffing of the breast feathers, dragging of the tail, cooing, and treading of the feet on the floor. If the female is receptive she will nod her head, after which billing follows. The male presents an open beak into which the female inserts hers. There is evidence that the male regurgitates into the beak of the female. Subsequently the female will crouch, elevate her wings and receive the male, and the pair-bond is formed (Whitman, 1919; Craig, 1918; Gifford, 1941).

\footnotetext{
*Corresponding e-mail address: nhparvez76@gmail.com Copyright (c) 2016 Bangladesh Society for Veterinary Medicine
} 


\section{MATERIALS AND METHODS}

The experiment was conducted at the Department of Veterinary and Animal Sciences, Faculty of Agriculture, Rajshahi University, Rajshahi from June 2015 to June 2016. 30 selected pigeon farms of three districts (Rajshahi, Natore \& Pabna) of Rajshahi division have been visited and the different breeds of pigeons were recorded. The pigeons were reared in scavenging condition and nests were used as a night shelter for protection against predator. Each pair of pigeon was kept in nest separately. The size of each nest was $32 \mathrm{~cm} \times$ $60 \mathrm{~cm} \times 22 \mathrm{~cm}$. Nest was made strong with iron and was placed at a reasonable height using strong support. The pigeons were offered high quality diets and water ad libitum with high and low protein level. One pair of pigeon requires about $60 \mathrm{gm}$ feed per day. The nests were cleaned periodically for maintaining good body condition of bird. The pigeons were treated with vaccine and deworming. The lengths of bill, head, body, shank, wing span and eggs were measured with slide calipers and measuring tape. Body weights were measured with an electronic balance in the morning before the birds were fed. Birds were individually observed for phenotype expression. For each pair of pigeon, different record sheets with full details of each parameter were maintained. The data generated from this experiment were entered in Microsoft Excel work sheet, organized and processed for further analysis. Mean, Standard errors (SE) and correlations were estimated with the help of statistical package for social science (SPSS, 2008)

\section{RESULTS AND DISCUSSION}

The color of body, bill, skin, shank, toe, eye, eyelid, eggs, and head, neck, body, wing, tail and down feather, and shape of body, bill and eggs of different breeds of pigeon were presented in Table 1. The mean body length, wing span, shank length, bill length and head length of different breeds of pigeon were presented in Table 2 . The phenotypic correlation among body length, bill length, head length wing span, shank length, middle toe length and weight of mature pigeon were provided in Table 3.

Bhowmik et al. (2014) reported that the body length was $33.28 \mathrm{~cm}$ in Jalali pigeon, which was comparable to those results reported by David et al. (2001), Axelson and Messonnier (2005) but nearly similar to nun and mookee pigeons in this research findings. The body weight of pigeon varies according to the breed, nutrition and management. Darwati et al. (2010) reported that mean body weight of local pigeon on 4th week was 290.40gm. Bhowmik et al. (2014) found the mean body weight of Jalali pigeon was $275.59 \mathrm{gm}$ which also in partial agreement with Islam (2010) and Azad (2009). Islam (2010) found that live weight of Jalali and Giribaz pigeon were $237.20 \mathrm{gm}$ and $244.70 \mathrm{gm}$ respectively. Azad (2009) observed that live weight of Gola male and female pigeon were 304.10 and $257.50 \mathrm{gm}$, respectively. Bhowmik et al. (2014) found the mean wing span $64.37 \mathrm{~cm}$ of Jalali pigeon that is nearly $64.60 \mathrm{~cm}$ of Giribug in the present research work. Mayntz (2012) pointed out that the wing span of rock pigeon was 25 inch which is very lower from the present findings. Bhowmik et al. (2014) reported that the positive and significant correlation between body weight with body length, wing span, shank length and head length and also suggests that selection for any of these body parameters will cause direct improvement in body weight. Similar results have been reported by Mbap and Zakar (2000) and Okpeku et al. (2003). Many of the phenotypic correlations between body measurements were positive and high which also reported by Mancha (2004). Zickefoose (2012) found that adult pigeons have orange or reddish orange eyes which support these results in the present findings with the Giribug. Similar results were also found by Johnston (1992) in adult Rock pigeon. The body color of Jalali pigeon is in agreement with those of Axelson and Messonnier (2005) and Johnston (1992). Axelson and Messonnier (2005) documented that a mature pigeon has a basic color of dull grey with white rump and two large wing bars. Johnston (1992) found that body color of Rock pigeon (Columba livia) were green, gray, purple or violet, sheen or iridescence. Bhowmik et al. (2014) reported that the color of shank and toe of Jalali pigeon were red, are similar with those of Zickefoose (2012) and also similar with the present research findings. Gambo et al. (2014) reported that among the linear body parameters shank length is the best single predictor of body weight than the other body measurements in Japanese quail. Anebi (2010) had earlier reported a similar finding, although in the domestic pigeon, that shank length was the best predictor of body weight as compared with other body measurements. Bokhari (2002) reported that shank length serves as a reliable index of body weight during most of the pigeons' growing period. Gambo et al. (2014) also reported that age had very highly significant effects on all linear body parameters as similarly reported by Daikwo (2011). 
Table 1. Phenotypic characteristics of different breeds of pigeon

\begin{tabular}{|c|c|c|c|c|c|c|c|c|c|c|c|c|c|c|c|}
\hline \multirow[b]{2}{*}{ Parameters } & \multicolumn{15}{|c|}{ Observations in the breeds } \\
\hline & \begin{tabular}{|l|} 
Giribug \\
\end{tabular} & Kormona & Nun & Owl & Satinette & Mookee & Suachandan & Lakkha & \begin{tabular}{|l|} 
Jacobin \\
\end{tabular} & Bokhara & Shirajee & Homer & Pouter & King & Strasser \\
\hline Bill color & Black & White & White & White & White & White & White & White & White & White & White & White & White & White & Black \\
\hline \begin{tabular}{|l|}
$\begin{array}{l}\text { Eye color } \\
\text { (Cornea color) }\end{array}$ \\
\end{tabular} & Black & Black & Black & Black & Black & Black & Black & Black & Black & Black & Black & Black & Black & Black & Black \\
\hline $\begin{array}{l}\text { Cornea } \\
\text { encircling ring } \\
\text { color }\end{array}$ & Orange & Yellow & White & White & White & White & White & White & White & White & White & Yellow & Yellow & Yellow & Yellow \\
\hline Eyelid color & White & White & White & White & White & White & White & White & White & White & White & White & White & White & White \\
\hline \begin{tabular}{|l|} 
Skin color \\
\end{tabular} & Pink & Pink & Pink & Pink & Pink & Pink & Pink & Pink & Pink & Pink & Pink & Pink & Pink & Pink & Pink \\
\hline $\begin{array}{l}\text { Head feather } \\
\text { color }\end{array}$ & $\begin{array}{l}\text { Black and } \\
\text { white }\end{array}$ & White & Yellow & Yellow & White & White & Brown & White & White & Yellow & Black & Red & Yellow & White & Blue \\
\hline $\begin{array}{l}\text { Neck feather } \\
\text { color }\end{array}$ & $\begin{array}{l}\text { Greenish } \\
\text { black }\end{array}$ & Red & $\begin{array}{l}\begin{array}{l}\text { Yellow } \\
\text { white }\end{array} \\
\end{array}$ & Yellow & White & Black & Brown & White & Yellow & Yellow & $\begin{array}{l}\text { Black } \\
\text { white }\end{array}$ & Red & White & White & White \\
\hline $\begin{array}{l}\text { Body feather } \\
\text { color }\end{array}$ & White & Red & White & Yellow & White & Black & Ash & White & Yellow & Yellow & White & Red & White & White & White \\
\hline \begin{tabular}{|l|}
$\begin{array}{l}\text { Wing feather } \\
\text { color }\end{array}$ \\
\end{tabular} & \begin{tabular}{|l|}
$\begin{array}{l}\text { Black and } \\
\text { white }\end{array}$ \\
\end{tabular} & Red white & \begin{tabular}{|l|}
$\begin{array}{l}\text { Yellow } \\
\text { white }\end{array}$ \\
\end{tabular} & Yellow & Ash brown & Black & Ash & White & \begin{tabular}{|l|}
$\begin{array}{l}\text { Yellow } \\
\text { white }\end{array}$ \\
\end{tabular} & Yellow & White & Red & Yellow & White & Ash blue \\
\hline $\begin{array}{l}\begin{array}{l}\text { Tail feather } \\
\text { color }\end{array} \\
\end{array}$ & Black & Red & Yellow & Yellow & Black & Black & Ash & White & White & Yellow & White & $\begin{array}{l}\begin{array}{l}\text { Reddish } \\
\text { gray }\end{array} \\
\end{array}$ & Yellow & White & Ash black \\
\hline $\begin{array}{l}\text { Down feather } \\
\text { color }\end{array}$ & White & Red & White & Yellow & White & Black & Ash brown & White & Yellow & Yellow & White & Red & White & White & White \\
\hline Shank color & Red & Red & Red & Red & Red & Red & Red & Red & Red & Red & Red & Red & Red & Red & Red \\
\hline Toe color & \begin{tabular}{|l|} 
Red with \\
black claw
\end{tabular} & \begin{tabular}{|l|} 
Red with \\
white claw
\end{tabular} & \begin{tabular}{|l|}
$\begin{array}{l}\text { Red with } \\
\text { white } \\
\text { claw }\end{array}$ \\
\end{tabular} & \begin{tabular}{|l} 
Red with \\
white \\
claw
\end{tabular} & $\begin{array}{l}\text { Red with } \\
\text { White } \\
\text { claw }\end{array}$ & \begin{tabular}{|l|} 
Red with \\
black claw
\end{tabular} & $\begin{array}{l}\text { Red with } \\
\text { black claw }\end{array}$ & \begin{tabular}{|l} 
Red with \\
White \\
claw
\end{tabular} & \begin{tabular}{|l} 
Red with \\
white \\
claw
\end{tabular} & \begin{tabular}{|l|} 
Red with \\
white claw
\end{tabular} & \begin{tabular}{|l} 
Red with \\
White \\
claw
\end{tabular} & $\begin{array}{l}\text { Red with } \\
\text { white } \\
\text { claw }\end{array}$ & $\begin{array}{l}\text { Red with } \\
\text { White } \\
\text { claw }\end{array}$ & $\begin{array}{l}\text { Red with } \\
\text { black } \\
\text { claw }\end{array}$ & $\begin{array}{l}\text { Red with } \\
\text { black claw }\end{array}$ \\
\hline Egg color & White & White & White & White & White & White & White & White & White & White & White & White & White & White & White \\
\hline Bill shape & $\begin{array}{l}\text { Elongated } \\
\text { narrow and } \\
\text { curve }\end{array}$ & \begin{tabular}{|l|}
$\begin{array}{l}\text { Short and } \\
\text { curve }\end{array}$ \\
\end{tabular} & \begin{tabular}{|l|}
$\begin{array}{l}\text { Short and } \\
\text { curve }\end{array}$ \\
\end{tabular} & \begin{tabular}{|l|}
$\begin{array}{l}\text { Short and } \\
\text { straight }\end{array}$ \\
\end{tabular} & $\begin{array}{l}\text { Short and } \\
\text { curve }\end{array}$ & $\begin{array}{l}\text { Elongated } \\
\text { and curve }\end{array}$ & $\begin{array}{l}\text { Short and } \\
\text { curve }\end{array}$ & $\begin{array}{l}\text { Short and } \\
\text { curve }\end{array}$ & $\begin{array}{l}\text { Short and } \\
\text { straight }\end{array}$ & $\begin{array}{l}\text { Elongated } \\
\text { and curve }\end{array}$ & $\begin{array}{l}\text { Elongated } \\
\text { and curve }\end{array}$ & $\begin{array}{l}\text { Elongate } \\
\mathrm{d} \text { and } \\
\text { straight }\end{array}$ & $\begin{array}{l}\text { Elongated } \\
\text { and } \\
\text { straight }\end{array}$ & Elongated & \begin{tabular}{|l} 
Elongated \\
and \\
straight
\end{tabular} \\
\hline Body shape & $\begin{array}{l}\text { Elongated } \\
\text { and round }\end{array}$ & Round & Round & Round & Round & Round & Round & Round & \begin{tabular}{|l|} 
Elongated \\
round
\end{tabular} & $\begin{array}{l}\text { Elongated } \\
\text { and round }\end{array}$ & $\begin{array}{l}\text { Elongated } \\
\text { and round }\end{array}$ & $\begin{array}{l}\text { Elongate } \\
\mathrm{d} \text { round }\end{array}$ & $\begin{array}{l}\text { Elongated } \\
\text { and round }\end{array}$ & Round & $\begin{array}{l}\text { Elongated } \\
\text { and round }\end{array}$ \\
\hline Egg shape & Oval & Oval & Oval & Oval & Oval & Oval & Oval & Oval & Oval & Oval & Oval & Oval & Oval & Oval & Oval \\
\hline
\end{tabular}




\section{M.N.H. Parvez and others}

Table 2. Effect of breed on body biometry of different breeds of pigeon $\quad(n=20)$

\begin{tabular}{|c|c|c|c|c|c|c|c|}
\hline \multirow{2}{*}{$\begin{array}{c}\text { Name of the } \\
\text { breeds }\end{array}$} & \multicolumn{7}{|c|}{ Parameters } \\
\hline & $\begin{array}{c}\text { Bill } \\
\text { length }(\mathrm{cm})\end{array}$ & $\begin{array}{l}\text { Head length } \\
\text { (cm) }\end{array}$ & $\begin{array}{l}\text { Body length } \\
(\mathrm{cm})\end{array}$ & $\begin{array}{l}\text { Wing span } \\
(\mathrm{cm})\end{array}$ & $\begin{array}{c}\text { Shank } \\
\text { length }(\mathrm{cm})\end{array}$ & $\begin{array}{l}\text { Middle toe } \\
\text { length }(\mathrm{cm})\end{array}$ & $\begin{array}{l}\text { Mature body } \\
\text { weight(gm) }\end{array}$ \\
\hline Giribug & $1.90 \pm 0.05^{\mathrm{f}}$ & $5.70 \pm 0.11^{\text {de }}$ & $32.40 \pm 0.49^{\mathrm{ef}}$ & $64.60 \pm 0.63^{\mathrm{e}}$ & $2.50 \pm 0.00^{\mathrm{b}}$ & $3.10 \pm 0.05^{\mathrm{de}}$ & $265.10 \pm 7.03^{\mathrm{g}}$ \\
\hline Kormona & $1.50 \pm 0.00^{\mathrm{g}}$ & $5.00 \pm 0.00^{\mathrm{f}}$ & $30.95 \pm 0.20^{\mathrm{fg}}$ & $60.45 \pm 0.76^{\mathrm{f}}$ & $2.50 \pm 0.00^{\mathrm{e}}$ & $3.00 \pm 0.00^{\mathrm{e}}$ & $269.10 \pm 6.05^{\mathrm{g}}$ \\
\hline Nun & $1.50 \pm 0.00^{\mathrm{g}}$ & $5.00 \pm 0.00^{\mathrm{f}}$ & $33.10 \pm 0.38^{\mathrm{de}}$ & $63.30 \pm 0.47^{\mathrm{e}}$ & $2.50 \pm 0.00^{\mathrm{e}}$ & $3.05 \pm 0.03^{\mathrm{e}}$ & $289.35 \pm 5.78^{\mathrm{fg}}$ \\
\hline Owl & $1.50 \pm 0.00^{\mathrm{g}}$ & $6.00 \pm 0.18^{\mathrm{cd}}$ & $30.00 \pm 0.43^{\mathrm{g}}$ & $63.20 \pm 0.80^{\mathrm{e}}$ & $2.80 \pm 0.06^{\mathrm{d}}$ & $3.30 \pm 0.06^{\mathrm{d}}$ & $301.80 \pm 9.55^{\mathrm{f}}$ \\
\hline Satinette & $1.50 \pm 0.00^{\mathrm{g}}$ & $6.00 \pm 0.00^{\mathrm{cd}}$ & $32.50 \pm 0.36^{\mathrm{ef}}$ & $60.80 \pm 0.67^{\mathrm{f}}$ & $2.50 \pm 0.00^{\mathrm{e}}$ & $3.00 \pm 0.00^{\mathrm{e}}$ & $332.85 \pm 5.30^{\mathrm{e}}$ \\
\hline Mookee & $2.00 \pm 0.00^{\mathrm{e}}$ & $5.60 \pm 0.11^{\mathrm{e}}$ & $33.00 \pm 0.53^{\mathrm{de}}$ & $64.80 \pm 0.80^{\mathrm{e}}$ & $2.60 \pm 0.05^{\mathrm{e}}$ & $3.30 \pm 0.06^{\mathrm{d}}$ & $333.75 \pm 6.36^{\mathrm{e}}$ \\
\hline Suachandan & $1.85 \pm 0.05^{\mathrm{f}}$ & $5.70 \pm 0.11^{\mathrm{de}}$ & $34.60 \pm 0.61^{\mathrm{d}}$ & $64.70 \pm 0.38^{\mathrm{e}}$ & $2.50 \pm 0.00^{\mathrm{e}}$ & $3.15 \pm 0.05^{\mathrm{de}}$ & $336.50 \pm 12.04^{\mathrm{e}}$ \\
\hline Lakkha & $1.95 \pm 0.03^{\mathrm{ef}}$ & $6.00 \pm 0.00^{\mathrm{cd}}$ & $36.40 \pm 0.41^{\mathrm{c}}$ & $69.78 \pm 0.52^{\mathrm{d}}$ & $2.80 \pm 0.08^{\mathrm{d}}$ & $3.63 \pm 0.09^{\mathrm{c}}$ & $414.80 \pm 9.19^{\mathrm{d}}$ \\
\hline Jacobin & $1.85 \pm 0.05^{\mathrm{f}}$ & $5.00 \pm 0.00^{\mathrm{f}}$ & $37.50 \pm 0.39^{c}$ & $81.00 \pm 0.51^{\mathrm{a}}$ & $2.80 \pm 0.06^{\mathrm{d}}$ & $3.30 \pm 0.06^{\mathrm{d}}$ & $436.00 \pm 6.75^{\mathrm{d}}$ \\
\hline Bokhara & $2.20 \pm 0.06^{\mathrm{c}}$ & $6.00 \pm 0.18^{\mathrm{cd}}$ & $39.40 \pm 0.99^{\mathrm{b}}$ & $76.85 \pm 1.04^{\mathrm{b}}$ & $3.20 \pm 0.09^{b}$ & $4.28 \pm 0.13^{\mathrm{ab}}$ & $469.80 \pm 12.76^{\mathrm{c}}$ \\
\hline Shirajee & $2.50 \pm 0.00^{\mathrm{b}}$ & $5.90 \pm 0.12^{\mathrm{de}}$ & $37.55 \pm 0.48^{\mathrm{c}}$ & $73.70 \pm 1.38^{\mathrm{c}}$ & $3.00 \pm 0.00^{\mathrm{c}}$ & $4.15 \pm 0.00^{\mathrm{b}}$ & $481.75 \pm 19.13^{\mathrm{c}}$ \\
\hline Homer & $2.83 \pm 0.05^{\mathrm{a}}$ & $6.25 \pm 0.16^{\mathrm{c}}$ & $37.75 \pm 0.76^{\mathrm{c}}$ & $67.60 \pm 0.96^{\mathrm{d}}$ & $3.40 \pm 0.13^{\mathrm{a}}$ & $4.25 \pm 0.10^{\mathrm{ab}}$ & $496.40 \pm 13.34^{\mathrm{bc}}$ \\
\hline Pouter & $2.50 \pm 0.00^{\mathrm{b}}$ & $6.00 \pm 0.00^{\mathrm{cd}}$ & $41.15 \pm 0.61^{\mathrm{a}}$ & $77.40 \pm 0.67^{b}$ & $3.00 \pm 0.00^{\mathrm{c}}$ & $4.40 \pm 0.05^{\mathrm{a}}$ & $521.20 \pm 8.12^{\mathrm{b}}$ \\
\hline King & $2.10 \pm 0.05^{\mathrm{d}}$ & $6.65 \pm 0.17^{\mathrm{b}}$ & $37.30 \pm 0.80^{\mathrm{c}}$ & $69.25 \pm 0.89^{\mathrm{d}}$ & $3.08 \pm 0.04 b^{c}$ & $4.25 \pm 0.09^{\mathrm{ab}}$ & $727.20 \pm 10.38^{\mathrm{a}}$ \\
\hline Strasser & $2.50 \pm 0.00^{\mathrm{b}}$ & $8.00 \pm 0.00^{\mathrm{a}}$ & $41.60 \pm 0.38^{\mathrm{a}}$ & $75.80 \pm 1.07 \mathrm{~b}^{\mathrm{c}}$ & $3.00 \pm 0.09^{\mathrm{c}}$ & $4.35 \pm 0.12^{\mathrm{ab}}$ & $748.20 \pm 8.96^{\mathrm{a}}$ \\
\hline
\end{tabular}

Values are mean $\pm \mathrm{SE}, \mathrm{a}, \mathrm{b}, \mathrm{c}, \mathrm{d}, \mathrm{e}, \mathrm{f}, \mathrm{g}$ data in the column with different superscripts are significant from each other $(\mathrm{p}<0.05), \mathrm{n}=$ no. of observation.

Table 3. Correlation among different body parameters

\begin{tabular}{|c|c|c|c|c|c|c|c|}
\hline & $\begin{array}{c}\text { Mature } \\
\text { body } \\
\text { weight }\end{array}$ & $\begin{array}{c}\text { Body } \\
\text { Length }\end{array}$ & Bill length & $\begin{array}{c}\text { Head } \\
\text { Length }\end{array}$ & Wing Span & $\begin{array}{l}\text { Shank } \\
\text { Length }\end{array}$ & $\begin{array}{l}\text { Middle Toe } \\
\text { Length }\end{array}$ \\
\hline $\begin{array}{l}\text { Mature } \\
\text { body } \\
\text { weight } \\
\text { Body } \\
\text { Length }\end{array}$ & $0.723^{* *}$ & & & & & & \\
\hline Bill length & $0.631^{* *}$ & $0.691^{* *}$ & & & & & \\
\hline $\begin{array}{l}\text { Head } \\
\text { Length }\end{array}$ & $0.683^{* *}$ & $0.536^{* *}$ & $0.517^{* *}$ & & & & \\
\hline Wing Span & $0.595^{* *}$ & $0.754^{* *}$ & $0.500^{* *}$ & $0.233^{* *}$ & & & \\
\hline $\begin{array}{l}\text { Shank } \\
\text { Length }\end{array}$ & $0.509^{* * *}$ & $0.401^{* *}$ & $0.621^{* *}$ & $0.399^{* *}$ & $0.317^{* *}$ & & \\
\hline $\begin{array}{l}\text { Middle Toe } \\
\text { Length }\end{array}$ & $0.725^{* * *}$ & $0.610^{* *}$ & $0.743^{* *}$ & $0.506^{* * *}$ & $0.512^{* *}$ & $0.789^{* *}$ & \\
\hline
\end{tabular}

**Correlation is significant at the 0.01 level

\section{CONCLUSION}

Although breed characteristics is essential to formulate the conservation and improvement strategies for the breed, so it is possible to improve these pigeons through selection and other relevant breeding strategies, therefore phenotypic characterization is important to measure and describe genetic diversity in these resources as a basis for utilizing them sustainably. External measurements are most useful in determining the sex that is important to maintain an ideal farm. Therefore, as a genetics resource, it is inevitably necessary for these pigeons to be conserved. More information needs to be collected and assessed to prevent their possible extinction and to promote their utilization. Further country wide studies should emphasize the genetic characterization of these pigeons. 
Phenotypic characteristics and biometrical study on different breeds of pigeon

\section{ACKNOWLEDGEMENTS}

The authors are grateful to the Department of Veterinary and Animal Sciences, Rajshahi University and to the Krishi Gobeshona Foundation (KGF), Bangladesh for financial and laboratory support.

\section{REFERENCES}

1. Anebi PE (2010). Genetic Analysis of a Flock of Domestic Pigeons (Columba livia domestica). MSc. Thesis, Department of Animal Breeding and Physiology, Univ. of Agric. Makurdi. pp. 68.

2. Asaduzzaman M, Mahiuddin M, Howlider MAR, Hossain M and Yeasmin T (2009). Pigeon farming in Gouripur upazilla of Mymensingh district. Bangladesh Journal of Animal Science 38: 142-150.

3. Axelson R and Messonnier S (2005). Pigeons and Doves on LH. Life learn Inc. p. 212.

4. Azad, MAK. (2009). Nutrient Availability and Body Composition of Semi Scavenging Gola pigeon and Meat Yield of their Squab. MSc, Departent of Poultry Science, Bangladesh Agricultural University, Mymensingh, Bangladesh.

5. Bhowmik N, Mia MM and Rahman MA (2014). Morphometric measurements, productive and reproductive performance of jalali pigeon. International Journal of Development Research 4: 908-911.

6. Bokhari A (2002). Bokhari Poultry and Squab Farm of California. E-mail: azhar@ bokhari.com; Poultry Specialist.

7. Craig W (1918). Appetites and aversions as constituents of instincts. Biol. Bull. 34: 91-107.

8. Daikwo IS (2011). Genetic Studies on Japanese Quail (Coturnixcoturnix japonica) in a tropical environment. Ph.D. Thesis, College of Ani.Sc.Univ. Agric. Makurdi, Nigeria. 167pp.

9. Darwati S, Martojo H, Sumantri C, Sihombing DTH and Mardiastuti A (2010). Productivity, Repeatability of Productive and Reproductive traits of local Pigeon. Journal of Indonesian Tropical Animal and Agriculture 35: 268-274.

10. Essam AM (1997). Behaviour and management of pigeons. PhD, Faculty of Veterinary Medicine, Moshtohr, Zagazig University.

11. FAO (Food and Agricultural Organization). (2010). Draft guidelines for molecular characterization of animal genetic resources for food and agriculture. Rome: FAO.

12. Gambo D, Momoh OM, Dim NI and Kosshak AS (2014). Body parameters and prediction of body weight from linear body measurements in Coturnix quail. Livestock Research for Rural Development 26.

13. Gifford EW (1941). Taxonomy and habits of pigeons. Auk 58: 239-245.

14. Islam MR (2010). Pigeon farming and meat yield of some genetic groups in Mymensingh District. MSc, Departent of Poultry Science, Bangladesh Agricultural University, Mymensingh, Bangladesh.

15. Johnston RF (1992). Rock pigeon (Columba livia). The Birds of North America, No.13 (Poole, A., Stettenheim, P. and Gill, F. eds.). The Academy of Natural Sciences, Philadelphia, PA, and the American Ornithologists' Union, Washington D.C.

16. Johnston RF and Janiga M (1995). Feral pigeons. Oxford University Press, New York. Levi W (1957). The Pigeon Sumter, S. C. Levi Publishing Company, Inc. p. 537. ISBN 0853900132.

17. Marques SM, Quadros RM, Da-Silva CJ and Baldo M (2007). Parasites of pigeons (Columba livia) in urban areas of langes, Southern Brazil. Parasitologia Latinoamericana 62: 183-187.

18. Mbap ST (1985). The Performance of Local, Exotic and Hybrid Cattle at Ibadan and Vom in Nigeria. Ph.D. Thesis, University of Ibadan, Ibadan.

19. Mbap ST and Zakar H (2000). Characterization of local chickens in Yobe state, Nigeria. In: The Role of Agriculture in poultry in poverty Alleviation.

20. Mancha YP (2004). Characterization of local chickens in Northern part of the Jos Plateau. A PhD Thesis, Animal Production Programme, School of Agriculture, ATBU, Bauchi.

21. Mayntz M (2012). Rock pigeon. Birding/Wild Birds. http://www.birdingabout.com/homepage/rockpigeon.html.

22. Okpeku M, Orheruata M and Imumorin IG (2003). Phenotypic and genetic variation among local chicken in Edo State of Nigeria. In: Nigerian Livestock: A Goldmine for Economic Growth and Food Security. Proceedings of the 28th Annual Conference of the Nigerian Society for the Animal Production 16-20 March, Ibadan. pp: 119-121.

23. Sari B, Karatepe B, Karatepe M and Kara M (2008). Parasites of domestic pigeon (Columba livia domestica) and wild (Columba livia livia) pigeons in Niğde, Turkey. Bulletin of the Veterinary Institute in Pulawy. 52: 551-554.

24. SPSS (2008). This product uses Win Wrap Basic, Polar Engineering and Consulting. http://www.winwrap.com. http://www.spss.com

25. Whitman CO (1919). The behavior of pigeons. Post-humous works, ed. by H.A. Carr. Carnegie Inst. Wash., 257: 1161.

26. Zickefoose J (2012). Cool Facts about Pigeons. Cornell Lab of Ornithology, Cornell University, 159 Sapsucker Woods Road, New York: Ithaca. 